\title{
Biological Efficiency in Hair Sheep Reared in a Sustainable Farming System in the Ecuadorian Amazon Region
}

\author{
Moyano JC ${ }^{1,5 *}$, Marini PR ${ }^{2,3,6}$ and Fischman ML ${ }^{4,5,6}$ \\ ${ }^{1}$ Universidad Estatal Amazónica-Centro de Investigación, Posgrado and Conservación Amazónica - Ecuador, Argentina \\ ${ }^{2}$ Facultad de Ciencias Veterinarias-Universidad Nacional de Rosario - Argentina \\ ${ }^{3}$ Consejo de Investigaciones (CIC-UNR), Argentina \\ ${ }^{4}$ Universidad de Buenos Aires, Facultad de Ciencias Veterinarias, Argentina \\ ${ }^{5}$ Instituto de Investigación and Tecnología en Reproducción Animal (INITRA), Argentina \\ ${ }^{6}$ Centro Latinoamericano de Estudios de Problemáticas Lecheras (CLEPL), Argentina
}

Submission: April 19, 2019; Published: May 09, 2019

*Corresponding author: Moyano JC, Universidad Estatal Amazónica-Centro de Investigación, Posgrado and Conservación Amazónica - Ecuador, Instituto de Investigación and Tecnología en Reproducción Animal (INITRA), Buenos Aires, Argentina

\begin{abstract}
Agriculture is a feasible option for inhabitants of the Ecuadorian Amazon Region. For it to be efficient, it is essential that input technologies and processes that generate social, environmental and economic-productive benefits are applied without harming the sustainability of the system. The objective of the work was to evaluate the biological efficiency of hair sheep in the Ecuadorian Amazon Region through productive and reproductive indicators. The animals used - Blackbelly hair sheep - belong to the flock at the Centre for Research, Postgraduate Studies and the Conservation of Amazonian Biodiversity (CIPCA). They were reared over four hectares under the same environmental, nutritional and management conditions. The CIPCA is located in the Arosemena Tola canton, Napo province, Ecuador, 44km along the road between Puyo and Tena ( $01^{\circ} 14.325^{\prime}$ S, $077^{\circ} 53.134^{\prime}$ W). The trial was conducted between January 2015 and February 2018. Twenty-two females from 24 to 32 months of age with an average weight and standard deviation of $34 \pm 4 \mathrm{~kg}$ were used. Their diet was free grazing. They were divided into two groups: Group 1- forage plus a daily mineral supplementation from when their first offspring were weaned until the end of the trial and Group 2- forage only, without mineral supplementation. G1 delivered a total of 66 lambs both male and female, whereas G2 produced 45 . The average weight at birth decreased in G1 in the third and fourth deliveries, showing significant differences ( $\mathrm{p} \leq 0.05)$ when compared to G2. Conversely, the average weight at weaning increased in G1 in the second, third and fourth deliveries showing significant differences ( $\leq \leq 0.05)$ with G2. Group 1 showed an intermediate value of prolificacy (150\%), while Group 2 was below the minimum required (102\%). It is concluded that the group of hair sheep from the Ecuadorian Amazon Region supplemented with minerals were more biologically efficient than the group that were not given supplements.
\end{abstract}

Keywords: Hair sheep; Prolificacy; Biological efficiency; Grazing system

Abbrevations: CIPCA: Conservation of Amazonian Biodiversity; BW: Body Weight; TWE: Total Weight of Ewes; TWW: Total Weight at Weaning; WW: Weaning Weight

\section{Introduction}

Tropical areas make up a quarter of Ecuador's total area. The development of ovine farming has been slow in these areas, but there is a huge and diverse potential for implementing sheep meat production systems. Agriculture is a feasible option for inhabitants of the Ecuadorian Amazon Region. For it to be efficient, it is essential that input technologies and processes that generate social, environmental and economic-productive benefits are applied without harming the sustainability of the system. In this region, sheep farming represents an economic resource of approximately $0.5 \%$ of total income. Obtaining multiparous litters - instead of uniparous - is one of the goals that the producer would count on in order to improve her/his economic-productive income with the same capital (the sheep). Litter size is an important component of productivity in herds, contributing much more to the production of kilos of lambs weaned per sheep than their individual growth rate [1]. 
The factors that determine litter size are numerous:

a. genetic, such as breed and individual variation.

b. environmental, such as level of nutrition before and after service.

c. age.

d. number of previous deliveries, and

e. hormonal treatments [2].

It is affected mainly by the ovulatory rate, the number of fertilized oocytes and embryonic survival [3]. The Blackbelly breed has received great attention in recent years, as it is one of the few hair sheep breeds reared in the tropics that presents high prolificacy [4]. However, to date, said prolific potential has not been properly evaluated or exploited. The objective of this study was to evaluate the biological efficiency of hair sheep from the Ecuadorian Amazon Region through productive and reproductive indicators.

\section{Materials and Methods}

The animals used - Blackbelly hair sheep - belong to the flock at the Centre for Research, Postgraduate Studies and the Conservation of Amazonian Biodiversity (CIPCA). They were reared over four hectares under the same environmental, nutritional and management conditions. The CIPCA is located in the Arosemena Tola canton, Napo province, Ecuador, $44 \mathrm{~km}$ along the road between Puyo and Tena (coordinates: S 01 ¹4.325'; W077 ${ }^{\circ} 53.134^{\prime}$ ) and has 4 ha of pastureland. The environment is tropical, with an average annual rainfall of $4000 \mathrm{~mm}$, an average relative humidity of $80 \%$ and temperatures that vary between 15 and 25 ${ }^{\circ} \mathrm{C}$. Its topography is characterized by slightly undulating reliefs without steep slopes, distributed over large natural plateaus. The altitude varies between 580 and 990 meters above sea level. Although the soils have a very heterogeneous composition, most originate in fluvial sediments from the Andean region of the country. The trial was conducted between January 2015 and February 2018. Twenty-two females, from 24 to 32 months of age, with an average weight and standard deviation of $34 \pm 4 \mathrm{~kg}$ were used.

Feeding was free grazing, with grasses mainly composed of Brachiaria decumbens, Brachiaria brizantha Arachis pintoi, Desmodium ovalifolium and Stylosanthes guianensis. At the beginning, the animals presented a normal clinical state in terms of digestive, respiratory and circulatory function, body temperature, eating and social behaviour. The sheep remained in pasture from 7:00am to $4: 00 \mathrm{pm}$, then penned at night with water consumption at will. The sheep were divided into two groups: G1- forage plus supplementation (Pecutrin ${ }^{\circledR}$ mineral supplement plus vitamins A, D3 and E, Bayer HealthCare) daily from the weaning of their first offspring until the end of the trial and G2- forage only, without mineral supplementation.

The variables analysed were:

Body weight at birth, $\mathrm{kg}$ (BW)

Weaning weight, $\mathrm{kg}(\mathrm{WW})$

Total weight at birth in kg: $\Sigma$ of weights at birth (TWB)

Total weight at weaning in kg: $\Sigma$ of weights at weaning (TWW)

Average weight of the ewes in $\mathrm{kg}$ (WE)

Total weight of ewes in $\mathrm{kg}$ (TWE)

$\mathrm{Kg}$ of weaned lamb / kg of total ewe in\% = ((TWB-TWW) $/$ TWE) *100

Fertility performance index (lambs born / lambed ewes) *100

JMP version 5.0 for Windows (JMP®, SAS Institute, 2003) was used for the statistical analysis. To estimate the levels of significance between single births and multiple births, the Chisquare test $(\chi)$ was used. The confidence level for all the analyses was $95 \%$ and the standard error $\alpha<0.05$.

Results

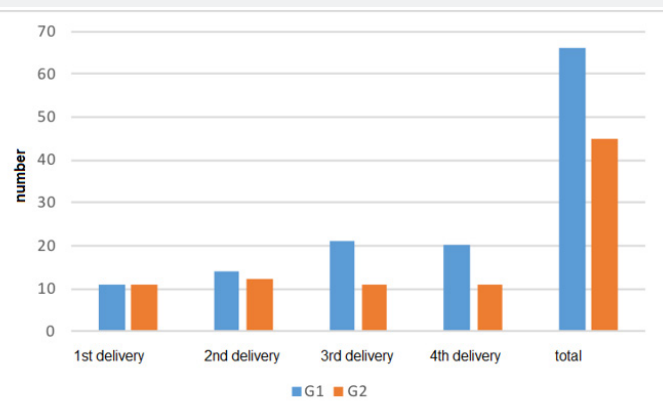

Figure 1: Number of lambs born per group and delivery number.

In Figure 1 it is observed that in the first delivery, 11 offspring from each group were obtained. As the deliveries progressed, G1 surpassed G2, having a greater number of twin births. By the end of the fourth deliveries, G1 had a total of 66 offspring both male and female, whereas G2 had 45. In the first delivery, in G1 only single births were recorded, in G2 a twin birth occurred and there were 
no significant differences between groups. In the second delivery, in G1 there were three twin births and eight single births, while in G2, two twin births were observed, with significant differences $(\mathrm{P}<0.05)$. In the third and fourth deliveries, in G1 twin births were observed in 9/11 and 8/11 mothers, whereas in G2, no twin births occurred in the third delivery and only one twin birth in the fourth and significant differences were found $(\mathrm{P}<0.001)$. Table 1 shows that the average birth weight decreased in G1 in the third and fourth deliveries, showing significant differences $(p \leq 0.05)$ when compared to G2. Conversely, the average weight at weaning increased in G1 in the second, third and fourth lambings, showing significant differences $(\mathrm{p} \leq 0.05)$ with G2. Table 2 shows that G1 produced higher total weights at birth as the number of deliveries advances, unlike G2 in which the figure decreased. In the same way, G1 yielded higher total weights at weaning as number of deliveries went up, whereas in G2 it decreased. If the total $\mathrm{kg}$ of weaned lamb in all four deliveries is added together (subtracting the birth weights of each of the deliveries), G1 produces $736.3 \mathrm{~kg}$ and G2 $433.9 \mathrm{~kg}$, with a difference of $302.4 \mathrm{~kg}$ for the same period.

Table 1: Average weights \pm standard error at birth and at weaning of the groups analysed over the period of four deliveries.

\begin{tabular}{|c|c|c|c|c|c|c|c|c|}
\hline & \multicolumn{2}{|c|}{ First Delivery } & Second Delivery & \multicolumn{2}{c|}{ Third Delivery } & \multicolumn{2}{c|}{ Fourth Delivery } \\
\hline & WB & WW & WB & WW & WB & WW & WB & WW \\
\hline G1 (11) & $2.9 \pm 0.2$ & $11.7 \pm 1$ & $2.4 \pm 0.2$ & $13.2 \pm 0.4^{*}$ & $1.5 \pm 0.1^{*}$ & $13.3 \pm 0.2^{*}$ & $1.6 \pm 0.1^{*}$ & $13.8 \pm 0.2^{*}$ \\
\hline G2 (10) & $2.8 \pm 0.2$ & $10.4 \pm 1$ & $2.5 \pm 0.2$ & $11.9 \pm 0.4$ & $2.5 \pm 0.1$ & $11.8 \pm 0.3$ & $2.2 \pm 0.1$ & $11.9 \pm 0.3$ \\
\hline \multicolumn{8}{|c|}{ NB: WB and WW are both in kg } \\
\hline
\end{tabular}

Table 2: Total weights at birth and at weaning in $\mathrm{kg}$ per group and delivery number.

\begin{tabular}{|c|c|c|c|c|c|c|c|c|}
\hline & \multicolumn{2}{|c|}{ First Delivery } & \multicolumn{2}{c|}{ Second Delivery } & \multicolumn{2}{c|}{ Third Delivery } & \multicolumn{2}{c|}{ Fourth Delivery } \\
\hline & TWB & TWW & TWB & TWW & TWB & TWW & TWB & TWW \\
\hline G1 (11) & 31.9 & 129 & 33 & 184.4 & 32.9 & 280.5 & 35 & 275.2 \\
\hline G2 (10) & 30.7 & 144.5 & 30.4 & 142.7 & 28 & 130 & 24.7 & 130.5 \\
\hline \multicolumn{4}{|c|}{ NB: TWB and TWW are both in kg } \\
\hline
\end{tabular}

Table 3: Average weights, standard error and total weights in $\mathrm{kg}$ of ewes per group and number of deliveries.

\begin{tabular}{|c|c|c|c|c|c|c|c|c|}
\hline & \multicolumn{2}{|c|}{ First Delivery } & \multicolumn{2}{c|}{ Second Delivery } & \multicolumn{2}{c|}{ Third Delivery } & \multicolumn{2}{c|}{ Fourth Delivery } \\
\hline & WE & TWE & WE & TWE & WE & TWE & WE & TWE \\
\hline G1 (11) & $41.1 \pm 0.9$ & 451.8 & $42.9 \pm 0.9$ & 472.3 & $44.9 \pm 1$ & 494 & $44.9 \pm 0.9$ & 495 \\
\hline G2 (10) & $34.2 \pm 0.9$ & 376.4 & $37.9 \pm 1$ & 380 & $38.1 \pm 1$ & 382 & $38.5 \pm 1$ & 385 \\
\hline & $*$ & $*$ & & $*$ & & $*$ & \\
\hline \multicolumn{8}{|c|}{ NB: WE and TWE are both in $\mathrm{kg}$} \\
\hline
\end{tabular}

Table 3 shows that the G1 ewes are heavier, showing significant differences ( $\mathrm{p} \leq 0.05)$, a fact that should be considered when comparing efficiency. Taking the weight of G2 as $100 \%$, G1 weigh $20 \%$ more, which is of course transferred in the same way to the total kg of each group. It is also observed that both groups gain weight after delivery has taken place. Upon analyzing the kg of weaned lamb / kg of ewe, it is observed that in G1 the value increases as the deliveries progress, which is explained by the greater number of twin births. In contrast, in G2 the production efficiency is maintained (kg produced / $\mathrm{kg}$ of sheep reared). If $\mathrm{kg}$ of weaned lamb / $\mathrm{kg}$ of total sheep is expressed as a percentage, it is observed that for G1 we obtain $21.9 \%, 32 \%, 50.1 \%$ and $48.5 \%$ efficiency, and for G2 $30.2 \%, 29.5 \%, 26.7 \%$ and $27.4 \%$ efficiency per kilogram of sheep reared. According to Bravo et al. (2012), the following values are considered to evaluate prolificacy: $\leq 120$ are low levels, values between 121 to 200 correspond to medium levels and values above $\geq 200$ correspond to higher levels. Based on this classification, Group 1 showed an intermediate level of prolificacy (150\%), while Group 2 was below the minimum required $(102 \%)$.

\section{Discussion}

Sheep production in tropical regions and especially in the Amazon region of Latin America has increased in recent years. These systems are characterized by low productivity and the majority use hair sheep breeds. From a comparative point of view with wool breeds, hair breeds are small, with a slow growth rate and poor muscular conformation, therefore wool and hair breeds have been crossed to improve growth rate [5]. The Blackbelly breed in particular is of great importance in the production of meat in the Ecuadorian Amazon Region, since it has adapted to the extreme conditions without affecting native flora and fauna, although it is an introduced species that is not endemic in the Ecuadorian Amazon Region. However, beyond adaptation to the environment, animals need balanced and adequate levels of all nutrients for their health and for production at any physiological 
stage [6]. Numerous authors have shown that one of the problems of grazing ruminants is that the grasses do not cover their protein, energy or mineral needs, which would affect the normal development of their metabolic processes [7], because their nutritional requirements depend exclusively on the composition of the forages [8]. The main micronutrient deficiency arises through inadequate dietary intake and during prenatal life from an inadequate transfer of placental nutrients.

These results coincide with what was found by Hulet [2] in relation to the importance of having an adequate level of nutrition before and after the service. Mineral supplementation in a systematic way would be reflected in a greater number of lambs at delivery (Figure 1), given that Group 1 outperformed Group 2 in the number of twin births over the study period (66 and 45 lambs, respectively by the end of the fourth delivery). In turn, Alonso Aguerrebere [9] concluded that the costs of production are calculated by considering the maintenance of the sheep throughout the different periods, thus any sheep that produces more than one lamb per delivery will reduce maintenance costs per lamb born. Consequently, animals of high prolificacy would allow for the obtaining of more lambs per ewe, reducing the maintenance costs of the mother per unit of production and also obtaining the benefits of a wide genetic selection and more rapid expansion of the sheep business. In this study, the overall birth weight mean was $2.74 \pm 0.74 \mathrm{~kg}$, similar to that published by Bores [10] for lambs of hair breeds, but lower than that which was observed in another study [11]. As the deliveries progressed, significant differences in birth weight were observed between G1 and G2 (Table 1). In turn, in the G1 a $60 \%$ decrease in the birth weight was observed in the offspring born in the third and fourth deliveries which were the product of the greater number of multiple births.

The mean weight at weaning was $11.37 \pm 0.38 \mathrm{~kg}$. This value was similar to findings by Bores [10], who reported weights of $12.0 \pm 0.4 ; 12.6 \pm 0.4$ and $13.8 \pm 0.5 \mathrm{~kg}$ for F1 hair sheep (Blackbelly $\mathrm{x}$ Pelibuey) and their crosses with Dorset, Suffolk and Hampshire breeds, respectively. However, our mean was lower than that found by Bonilla [12], who recorded weights of $14.3 \mathrm{~kg}$ for lambs of the Dorper and Katahdin breed crossed with Pelibuey. Likewise, other researchers [13-16] also registered higher weights than those reported in this study. These results coincide in part with studies which showed the difference in sheep's weight at birth according to whether they were single or multiple births. Differences in birth weight when comparing simple and multiple births would be due not only to a restricted uterine capacity, but also to a limited source of essential nutrients for large numbers of developing fetuses [17].

On the other hand, there was no correlation between these results and those reported by Rajab [18] who stated that the differences found in weight at weaning could be due to the greater weight of lambs born from single births than those from multiple births and the fact that sheep in multiple births competed for milk supplies. Regarding the average weight at weaning, from the second delivery there were significant differences between G1 and G2, which were maintained in the following births (Table 1). In G1 it was observed in the second, third and fourth deliveries that the offspring weighed $24 \%$ more than those corresponding to G2. In other words, despite having a lower weight at birth, the G1 lambs outweighed the G2 lambs.

The lambs' nutritional requirements are relatively low at this stage; therefore, this difference can be explained by the supplementation received by G1. For many years it was considered that supplementation under grazing conditions was not profitable. However, although the effect of supplementation is low when evaluated at an individual level, if it is analyzed per unit area and total $\mathrm{kg}$, it can be attractive, as evidenced in Table 2. In the same table it can be seen that the difference of $\mathrm{kg}$ of weaned sheep is higher in G1, which produces an average of $110 \%$ more weaned kg than in G2 between the second, third and fourth weaning stages. A strategy of selecting ewes that directly affects the productivity and profitability of the farm is to consider the kilograms of weaned lamb per ewe. This variable involves the factors that most influence the profitability of the herd, since it considers the ewe's prolificacy, milk production, maternal instinct, lamb mortality and lambs' weight gain. It can also be measured annually (kg of weaned lamb per ewe per year). Table 4 shows that as prolificacy increases, G1 more than doubles in the efficiency of the kg gained per kg of reared ewe. Now if we consider the difference of the ewe in each group, this efficiency is still higher but it would decrease to $25 \%$ higher. This shows the need to use aggregate indicators, since by itself the prolificacy would not be enough if it is not accompanied by a smaller sheep to reduce its maintenance in this efficiency.

Table 4: Average values of grams gained per $\mathrm{kg}$ of sheep reared.

\begin{tabular}{|c|c|c|c|c|}
\hline & First Delivery & Second Delivery & Third Delivery & Fourth Delivery \\
\hline G1 (11) & 0.215 & 0.321 & 0.501 & 0.485 \\
\hline G2 (10) & 0.302 & 0.296 & 0.267 & 0.274 \\
\hline \multicolumn{2}{|r|}{ NB: Kg of weaned lamb / kg of total ewe in = ((TWB-TWW) $/$ TWE) } \\
\hline
\end{tabular}

Numerous studies have shown that various nutritional factors have an influence on reproductive processes. However, most of the research emphasizes the final stages of gestation, due to the importance of detecting pre-eclampsia in the ewes and monitoring the lambs' survival and growth. Well-fed ewes do not always produce a greater number of lambs. The prolificacy was $150 \%$ for the G1 group and $102 \%$ for G2. These results are similar to those reported by other authors $[19,20]$, who found that Blackbelly sheep were significantly better $(\mathrm{P}<0.05)$ with a prolificacy of $110 \%$ compared to other breeds which had $92 \%$. 
In Cuba, prolificacy values ranging from 147 to $169 \%$ throughout the year have been found in the Pelibuey breed. The highest rates occurred in the months of June and July and the lowest in October and November. In Mexico, there are also studies that observed a decrease in reproductive activity [20-22], which had an impact on prolificacy, with values of 107 to $142 \%$. The highest rates were witnessed from September to December and lowest from January to April, which is considered to be the dry season.

\section{Conclusion}

It is concluded that the group of hair sheep from the Ecuadorian Amazon Region supplemented with minerals have been more biologically efficient than the non-supplemented group.

\section{Conflict of Interest}

The author declares that there is no conflict of interests.

\section{References}

1. Rojas-Rodriguez O, Rodriguez-Rivera OL (1995) Factores que modifican la prolificidad en ovejas Blackbelly en clima tropical. Tec Pecu Mex 33: 159-167.

2. Hulet CV (1977) Management the reproduction in sheep. Symposium of reproduction in sheep and goats. Sheep Industry Development Program, Inc pp. 119-133.

3. Hanrahan JP, Quirke JK (1985) Contribution of variation in ovulation rate and embryo survival to within breed variation in litter size. In Land, R. B. and D. W. Robinson (eds). Genetics 01 Reproduction in Sheep. Butterworths pp. 193-201.

4. Hermosillo GGA, Castaneda MJ, Banuelos DGJ (1990) Establecimiento de un módulo de mejoramiento genético de ovinos tropicales, en el sur de Jalisco, resultados iniciales, peso al nacimiento (PN). Memoria del III Congreso Nacional de Producción Ovina, Tlaxcala. Mexico, p. 66.

5. López-Carlos MA, Ramírez RG, Aguilera-Soto JI, Aréchiga CF, Rodríguez H (2010) Size and shape analyses in hair sheep ram lambs and its relationships with growth performance. Livest Sci 131: 203-211.

6. Barakat NA, Laudadio V, Cazzato E, Tufarelli V (2013) Potential contribution of retamaraetam (Forssk.) Webb \&Berthel as a forage shrubin Sinai, Egypt. Arid Land Res Manage 27: 257-271.

7. McDowell LR (2003) Minerals in Animal and Human Nutrition. $\left(2^{\text {nd }}\right.$ edn), Elsevier Science B.V., Amsterdam, The Netherlands, pp. 644.

8. Morales A, Domínguez EIV, González Ronquillo M, Jaramillo GE, Castelán 0, et al. (2007) Diagnóstico mineral en forraje y suero sanguíneo de bovinos lecheros en dos épocas en el valle central de México. Técnica Pecuaria México 45: 329-344.
9. Alonso AJI (1981) Manejo de la reproducción en el ovino. Ciencia Vet. 434-463.

10. Bores QR, Velázquez MA, Heredia AM (2002) Evaluación de razas terminales en esquemas de cruza comercial con ovejas de pelo F1. Téc Pecu Méx 40(1): 71-79.

11. Puga HP, Martínez JC, Cienfuegos EG, Briones F (2007) Comportamiento de peso al nacimiento de un rebaño de ovinos de pelo en el centro de Tamaulipas.

12. Bonilla TG, Aguilar ES, Ortega JE, Torres HG (2003) Crecimiento predestete de corderos Pelibuey y F1 Kathadin x Pelibuey en condiciones tropicales. Memorias XII Congresod e producción Ovina. Tulancingo, Hidalgo, México.

13. González GR, Torres G, Castillo M (2002) Crecimiento de corderos Blackbelly entre el nacimiento y el peso fi nal en el trópico húmedo de México. Vet. México, 33(4): 443-454.

14. Estrada AA, Sierra TJS, Gutiérrez RE (2004) Evaluación de la productividad de ovinos de la raza Pelibuey y sus cruzas con Dorper. Memorias XL Congreso Nacional de Investigación Pecuaria. Mérida, Yucatán, México, pp. 227.

15. Loya HFM, Martínez I, Chávez JA, Vázquez JF, Cienfuegos EG, et al (2003) Efecto del tipo de energía en la dieta sobre el comportamiento productivo en corderos de razas de Pelo. Memoria XII Congreso Nacional de Producción Ovina. Tulancingo, Hidalgo, México.

16. Pérez CR, Vázquez C, Sosa C, Valencia M, González E (2005) Factores que infl uyen sobré el peso al nacimiento y al destete en corderos Pelibuey y Blackbelly. BIOTAM Nueva Serie pp. 403-405.

17. Yazdi MH, Johanson K, Gates P, Näsholm A, Jorjani H, et al. (1999) Bayesian analysis of birth weight and litter size in Balushi sheep using Gibb's sampling. J Anim Sci 73: 533- 540.

18. Rajab MH, Cartwright TC, Dahm PF, Figueiredo EAP (1992) Performance of three tropical hair sheep breeds. J Anim Sci 70: 3351-3359.

19. González Reyna A (1983) Toe postpartum period in the Pelibuey ewe. Ph.D. Thesis. University of Saskatchewan, Saskatoon, Saskatchewan, Cariada, pp. 316.

20. Valencia, M, González E (1983) Pelibuey sheep in México. In: Fitzhugh HA, Bradford GE (Eds.). Hair Sheep of West Africa and the Americas. A Genetic Resource for the Tropics. West View Press, pp. 235.

21. Trejo GA, Perez RY, Soto GR, Gonzalez DF, Frey SE (1990) Algunos parametros productivos y reproductivos en ovinos Pelibuey en un rebafio comercial de Chalma, Edo. México. Memorias del III Congreso Nacional de Produccion Ovina. Tlaxcala, Mexico, pp. 117.

22. Congreso Nacional de Buiatría XIII Congreso Latinoamericano de Buiatría. AMMVEB. Acapulco, Guerrero, México, pp. 682-685. 
This work is licensed under Creative Commons Attribution 4.0 License

DOI: 10.19080/JDVS.2019.11.555820

\section{Your next submission with Juniper Publishers will reach you the below assets}

- Quality Editorial service

- Swift Peer Review

- Reprints availability

- E-prints Service

- Manuscript Podcast for convenient understanding

- Global attainment for your research

- Manuscript accessibility in different formats ( Pdf, E-pub, Full Text, Audio)

- Unceasing customer service

Track the below URL for one-step submission https://juniperpublishers.com/online-submission.php 